\title{
Meat Quality and Volatile Flavor Traits of Duroc, Berkshire and Yorksire Breeds
}

\author{
Dashdorj Dashmaa, Byung-Wook Cho ${ }^{1}$, Ganbat Odkhuu, Kyoung-Mi Park, Kyoung-Tag Do ${ }^{1}$, \\ $\mathrm{Ki}-\mathrm{H} w a n \mathrm{Lee}^{2}$, Kang-Seok $\mathrm{Seo}^{3}$, Jae-Gwan $\mathrm{Choi}^{4}$, Moon-Jun Lee ${ }^{5}$, In-Kyung $\mathrm{Cho}^{6}$, \\ Kyeong-Seon Ryu, Dawoon Jeong, and Inho Hwang* \\ Department of Animal Science and Institute of Rare Earth for Biological Application, Chonbuk National University, \\ Јеonju 561-756, Korea \\ ${ }^{1}$ Department of Animal Science, Pusan National University, Miryang 627-706, Korea \\ ${ }^{2}$ Korea Animal Improvement Association, Seoul 137-871, Korea \\ ${ }^{3}$ Department of Animal Resources Science, Suncheon National University, Sunchon 540-742, Korea \\ ${ }^{4}$ National Institute of Animal Science, R.D.A., Chaenon 331-801, Korea \\ ${ }^{5}$ Department of Food Science and Biotechnology, Chonbuk National University, Iksan 570-752, Korea \\ ${ }^{6}$ Department of Food and Nutrition Nambu University, Gwangju 506-824, Korea
}

\begin{abstract}
The present study evaluated the difference in objective and subjective meat quality properties among the pure-breed boars of Duroc, Berkshire and Yorkshire. Ten longissimus lumborum (LD) muscles were collected from each breed after $24 \mathrm{~h}$ slaughtering. The breed type showed a significant effect on intramuscular fat content, moisture $(p<0.01), \mathrm{pH}$, sarcoplasmic protein solubility and color $(p<0.05)$, whereas cooking loss and Warner Blazer shear force (WBsf) did not differ among the breeds. The Yorkshire breed showed significant $(p<0.05)$ lower sarcoplasmic protein solubility, $\mathrm{pH}$ and CIE a* value when compared with other breeds. The sensory panels identified Duroc as having greater overall acceptability and higher rating values than other breeds. The oleic acid content was significantly lower in the Berkshire $(29.85 \%)$ than in the Duroc (40.19 $\%)$ and Yorkshire breeds $(38.18 \%, p<0.05)$. The Yorkshire breed showed the most desirable ratio of polyunsaturated and saturated fatty acids $(0.31)$ than the Berkshire $(0.16)$ and Duroc breeds $(0.15, p<0.05) .40$ volatile compounds have been identified and quantified, while aldehydes were the most abundant among flavor substances. Aldehydes were negatively correlated with oleic acid content $(p<0.05)$. Current data indicated that each breed had their own merits and deficiencies in terms of meat qualityThe Yorkshire breed showed a greater number of weak points. Furthermore, this study indicated that individual fat-driven flavor components were greatly influenced by fatty acid composition. The polyunsaturated fatty acids did not show any negative effects on meat flavor if cooked meats were consumed soon after cooking.
\end{abstract}

Key words: breed, fatty acids, flavor, pork, volatiles

\section{Introduction}

The eating quality introduction of pork is a complex term consisting of multi-attributes of consumer acceptance and palatability such as tenderness, flavor and juiciness (Crawford et al., 2010). The studies have identified a number of intrinsic and extrinsic factors affecting eating quality of pork including breed (Brewer, 2002; Laack et al., 2001), intramuscular fat content (Bejerholm and

\footnotetext{
*Corresponding author: Inho Hwang, Department of Animal Science, Chonbuk National University, Jeonju 561-756, Korea Tel: 82-63-270-2605, Fax: 82-63-270-2605, E-mail: inho.hwang (a)chonbuk.ac.kr
}

Aaslyng, 2003) and pH (Cho et al., 2009; Huff-Lonergan et al., 2002).

There are number of studies have attempted to identify the best premium pig breed in terms of productivity, carcass and eating quality (Newcom et al., 2004; Wood et al., 1996; Yang et al., 2009). The breed, Berkshire showed a higher $\mathrm{pH}$ than other commercial pig breeds. These characteristics were consequently attributed to higher overall liking score (Wood et al., 2004, 1996) and more acceptable likeness compared to European commercial pork breeds (Ellis et al., 1996). In addition, purebred Duroc tended to have higher redness than Landrace (Cameron et al., 1990; Newcom et al., 2004). Edwards et al. (2003) found that no significant difference in color 
within the same sire lines of Duroc, Chinese, and Pietrain breeds. Our previous study (Park et al., 2007) reported that a higher redness of Korean native pig compared with Landrace, was related to a higher content of myosin heavy chain (more an oxidative fiber type). In addition, it has been received a great attention that pig breed have different fatty acid profile (Wood et al., 2004) because the ratio of polyunsaturated and saturated fats are important viewpoint of healthy food (Leong et al., 2010; Warnants et al., 1998).

The threshold value (2-3\%) of intramuscular fat content was required for optimal tenderness of pork (Jeremiah and Miller 1998), but Eikelenboom et al. (1996) reported that $\mathrm{pH}$ was more important than intramuscular fat content for quality. The $\mathrm{pH}$ of meat has a great effect on objective meat quality and palatability (Savell et al., 2005) through its effects on water-holding capacity (Bryhni et al., 2002; Huff-Lonergan et al., 2005), protein solubility and surface reflectance of meat (Hwang et al., 2003; Joo et al., 1999). Scheffler et al. (2007) reported that subnormal low $\mathrm{pH}$ cause denaturation of sarcoplasmic and myofibriilar proteins, resulting in pale color and reduced water-holding capacity. The higher $\mathrm{pH}$ had superior quality on the pork compared to lower $\mathrm{pH}$, and the higher $\mathrm{pH}$ also showed stability of meat color significantly (Graziotti et al., 2011; Holmer, 2009; Obi et al., 2010). On the other hand, in terms of flavor aspect, the higher level of polyunsaturated fatty acids negatively affect on meat flavor (Cameron et al., 2000).

The flavor intensity and volatile species are necessary for cooked meats. The flavor properties of raw meat is meaty or bloody note, but numerous volatile components are generated during cooking through the Maillard reactions of amino acids with reducing sugars, thermal degradation of fatty acids, vitamin degradation and interaction between the intermediates of Maillard reaction with lipiddegraded products during cooking (Mottram, 1994). The dimethyl sulphide, 2-butanone, ethyl acetate, 2- and 3methylbutanal, 2-heptanone, dimethyl trisulphide and nonanal were detected as key flavor of cooked meats (Leong et al., 2010; Machiel et al., 2003). On the other hand, our model study revealed that fatty acid composition and protein degradation by postmortem proteolysis activity had a great effect on amount and flavor component (Ba et al., 2010). This result suggested that breed and fatty composition generate different flavor species such as free amino acids/peptides, fatty acids, reducing sugars in meats greatly affect ultimate flavor notes through their effects on the reactions, oxidation and deg- radation processes on heating (Elmore et al., 2004). Hence, our experiments are designed to find differences of meat quality by using different purebred pigs and to provide information about correlations of meat quality, fatty acid and flavor for selecting boars.

\section{Materials and Methods}

\section{Animals and sampling}

A total of thirty purebred boars (Duroc $n=10$, Berkshire $\mathrm{n}=10$, Yorkshire $\mathrm{n}=10$ ) were sampled from a commercial breeding farm and weighed about $101 \pm 0.35 \mathrm{~kg}$. The animals were transported to a commercial abattoir within $100 \mathrm{~km}$ with minimum handling-stress and laired overnight with drinking water. The carcasses were chilled overnight at a $4^{\circ} \mathrm{C}$ in cold room, and graded by a meat grader according to the Korean grading standard (NLCF, 2004). M. longissimus lumborum (LD) was separated from the right side of the carcasses and moved to the meat science Laboratory of the Chonbuk National University. These LD sample was divided to each analysis, the contents was packed with vacuum, stored at $-20^{\circ} \mathrm{C}$ until analysis.

\section{Objective and subjective quality}

The $\mathrm{pH}$ was measured using a portable $\mathrm{pH}$ meter (301, Orion, USA). The $1 \mathrm{~g}$ of muscle sample was homogenized twice with $10 \mathrm{~mL} \mathrm{KCl}$ solution $(5 \mathrm{mM}$ iodoacetate $\mathrm{KCl} ; \mathrm{w} / \mathrm{v}$ ) for $30 \mathrm{sec}$ at $11,000 \mathrm{rpm}$ with $15 \mathrm{sec}$ break using the Ultraturrax T25B (IKA works, Malaysia) and $\mathrm{pH}$ was measured at $25^{\circ} \mathrm{C}$.

The meat color, cooking loss and Warner Blazer share force (WBsf) were analyzed as the protocols of Cho et al. (2009). The frozen samples were thawed overnight at $4^{\circ} \mathrm{C}$ and trimmed and cut $5 \mathrm{~mm}$ thickness of top to expose fresh surface. The objective meat color (CIE L*, a*, b*; lightness, redness, yellowness) was measured after a 30 min blooming at $4^{\circ} \mathrm{C}(\mathrm{CM}-2500 \mathrm{~d}$, Konica Minolta, Japan). For cooking loss and WBSF measurements, approximately $350 \mathrm{~g}(5 \times 6 \times 7 \mathrm{~cm})$ of meat blocks were trimmed and cooked in $70^{\circ} \mathrm{C}$ water bath for 60 min until the sample block reached $70^{\circ} \mathrm{C}$. The cooked samples were cooled in $18^{\circ} \mathrm{C}$ running water for $30 \mathrm{~min}$. WBsf was determined from an average of 6 cores from the cooked sample block using an Instron (3342, Instron, USA), and the measurement condition was $400 \mathrm{~mm} / \mathrm{min}$ head speed, $40 \mathrm{~kg}$ load cell. The weight loss before and after cooking was expressed as a percentage weight of the initial cooking block and used as a cooking loss. 
The protein solubility was determined by dissolving $1 \mathrm{~g}$ of muscle tissue in $10 \mathrm{~mL}$ of ice-chilled potassium phosphate buffer ( $\mathrm{pH}$ 7.2) according to the method described by Warner et al. (1997). Briefly, $1 \mathrm{~g}$ of meat sample was homogenized with $20 \mathrm{~mL}$ of extraction buffer by an ultra Turrax T25B (IKA, Malaysia) at $11.000 \mathrm{rpm}$ with $4 \mathrm{~s}$ burst and $10 \mathrm{~s}$ break. The homogenate were kept overnight in ice and centrifuged at $1500 \mathrm{~g}$ at $4^{\circ} \mathrm{C}$ for $20 \mathrm{~min}$. $1 \mathrm{~mL}$ of supernatant was taken and protein concentration of the supernatant was determined, and it was expressed as $\mathrm{mg} / \mathrm{g}$ tissue. The myofibrillar protein solubility was calculated as the difference between total and sarcoplasmic protein solubility. Moisture content was analyzed using the HR 73 halogen moisture analyzer (MettlerToledo, Switzerland). The crude fat content was analyzed using the Soxhlet extraction method with petroleum ether (AOAC, 2006). $5 \mathrm{~g}$ of sample was minced and placed in an extraction thimble, dried at $102^{\circ} \mathrm{C}$ for $5 \mathrm{~h}$, cooled in a desiccator at room-temperature, and extracted using Soxhlet extractor by petroleum ether for $6 \mathrm{~h}$. Crude fat content was expressed as weight percentage of wet muscle weight.

Sensory evaluation was performed following method of Hwang et al. (2008). Sensory panels were recruited from a university group, consisting of 48 male and female students. A total of 288 sensory samples were randomly allocated in 12 sets of four sessions; each session had 12 panelists and each panelist evaluated 6 samples. A total of twelve thin slices $(30 \times 30 \times 4 \mathrm{~mm})$ for each sensory samples was cut parallel to fiber direction. Samples were again vacuum-packed and stored in the freezer set at $-20^{\circ} \mathrm{C}$ until analysis. Samples allotted for session were thawed for $30 \mathrm{~min}$ before the scheduled sensory panel. The vacuum-packed meats were opened only when the samples are about to be cooked. Cooking was done on open tincoated grill (surface temperature: $240-250^{\circ} \mathrm{C}$ ). Two sets of grill were used where each grill was set to cook 6 strips of samples. The twelve cooked samples were immediately served to designated panelists. Panelists rated tenderness, juiciness and flavor using $10 \mathrm{~cm}$ unstructured line scale with verbal anchors based on quantitative descriptive analysis was used, where the left anchor represented scoring of either tough, dry, extremely dislike the flavor or sample is extremely unacceptable. After evaluating each sample, the panelists were asked to refresh their mouth with the provided distilled drinking water and saltfree crackers.

\section{Fatty acid analysis}

Fatty acid composition was determined by the procedure developed by Rule (1997). The meat samples were pulverized after freeze dried for 48 h. $500 \mathrm{mg}$ of pulverized meat sample was placed into a $20 \mathrm{~mL}$ headspace vial with silicone-lined cap, and $2 \mathrm{~mL}$ of $14 \%$ borontrifluoride in methanol was added. The mixture was vortex-mixed every $5 \mathrm{~min}$ for $2 \mathrm{~h}$ at $80^{\circ} \mathrm{C}$, then $3 \mathrm{~mL}$ of distilled water and $3 \mathrm{~mL}$ of hexane were added. The mixture was cooled, capped and vortex-mixed for $15 \mathrm{~min}$. One $\mathrm{mL}$ of the upper hexane phase was transferred to GLC auto-sampler vials after centrifugation at $1000 \mathrm{~g}$ for $5 \mathrm{~min}$ and stored at $-20^{\circ} \mathrm{C}$ until analysis. Fatty acid analysis was performed by a gas chromatography (GC-MS Agilent $6890 \mathrm{~N}$ equipped with Fused silica capillary column $30 \mathrm{~m} \times 0.25 \mathrm{~mm} \times 0.25$ $\mu \mathrm{m}$ film thickness with helium carrier gas and split ratio of 100:1) at the total running time of $35 \mathrm{~min}$. Sample inlet and oven chamber temperatures were $250^{\circ} \mathrm{C}$. A linear elevation of oven temperatures were programmed as $50^{\circ} \mathrm{C}$ for $1 \mathrm{~min}, 200^{\circ} \mathrm{C}$ at the rate of $25^{\circ} \mathrm{C}$ per min, $230^{\circ} \mathrm{C}$ at the rate of $3^{\circ} \mathrm{C} / \mathrm{min}$. Detector temperature was $280^{\circ} \mathrm{C}$. Individual fatty acid peaks were identified by comparing the retention times with known standards of fatty acid and composition expressed as percentage of the total fatty acid methyl esters (Supelco F.A.M.E, Mix C8-C24).

\section{Volatile compounds analysis}

For volatile flavor components, $1 \mathrm{~g}$ of sample was powdered in liquid nitrogen and placed in a $40 \mathrm{~mL}$ headspace vial sealed with PTFE-faced silicone septum (Supelco Co., USA) and heated in an autoclave at $132^{\circ} \mathrm{C}$ for 30 min. The sample was immediately cooled in an ice bath for $10 \mathrm{~min}$ to avoid further aroma development, thereafter equilibrated at $60^{\circ} \mathrm{C}$ for $10 \mathrm{~min}$. Water bath temperature was monitored by a temperature data logger (TR-52, T \& D, Japan). The SPME needle (Carboxen/PDMS, $75 \mu \mathrm{m}$, Supelco Co., USA) was inserted into the PTFE/silicone septum and the fiber was exposed after the 10 min-equilibration period. The extraction process for volatiles was carried out at $60 \mathrm{~min}$ (Moon and Li Chan, 2004). A DB$5 \mathrm{MS}$ capillary column $(30 \mathrm{~m} \times 0.25 \mathrm{~mm}$ i.d. $\times 0.25 \mu \mathrm{m}$ film thickness, Agilent J \& W Scientific, Model No. 122-5532, USA) was aged overnight at $230^{\circ} \mathrm{C}$. The SPME fiber was desorbed at $250^{\circ} \mathrm{C}$ for $5 \mathrm{~min}$. Carrier gas, split ratio, split flow and flow rate were helium, 10:1 and $10 \mathrm{~mL} / \mathrm{min}$ and $1.0 \mathrm{~mL} / \mathrm{min}$, respectively. Oven temperatures were programmed as $40^{\circ} \mathrm{C}$ with $5 \mathrm{~min}, 250^{\circ} \mathrm{C}$ at the rate of $25^{\circ} \mathrm{C} /$ min, and $250^{\circ} \mathrm{C}$ at $31.25^{\circ} \mathrm{C}$ min (Ba et al., 2010; Schilling et al., 2009). The area of each peak was integrated using the ChemStation software (Agilent Technologies, USA), 
and peaks were identified by Kovats index calculated by applying a series of standard alkanes C8-C20 (Fluka, Cat. No. 04070, New Zealand).

\section{Statistical analysis}

Least square means for the breed effects were stated using the general linear models of SAS program (SAS, 2007), and significant difference between means were examined at 5\% threshold. Pearson's correlation coefficient were evaluated using Corr. procedure to describe the relationships between breeds, $\mathrm{pH}$ and meat quality traits.

\section{Results and Discussion}

\section{Effects of breed on objective and subjective meat quality traits}

Least square means and their significant level as a function of the breed on objective meat quality and sensory traits are presented in Tables 1 and 2. Initially, most factors related to meat carcass and meat quality were greatly influenced by breed in that intramuscular fat content, sarcoplasmic protein solubility, $\mathrm{pH}$, meat color, overall acceptability of consumer panels were particularly significant $(p<0.05)$. There are several studies demonstrated that level of intramuscular fat content greatly influence on eating quality (Wood et al., 1996). In this study, intramuscular fat content of different breed showed a significant difference $(p<0.001)$, where Duroc longissimus muscle contained the highest level of intramuscular fat content with the lowest of water level among breeds (Table 1). Similar to the other study (Wood et al, 1996), the higher concentration of intramuscular fat improved $(p<0.05)$ eat-

Table 1. Breed effect on objective meat quality traits of longissimus lumborum muscle from Duroc, Berkshier and Yorkshire

\begin{tabular}{|c|c|c|c|c|}
\hline \multirow{2}{*}{ Trait } & \multicolumn{3}{|c|}{ Breed } & \multirow{2}{*}{$P$ value } \\
\hline & Duroc & Berkshire & Yorkshire & \\
\hline Intramuscular fat content (\%) & $3.28 \pm 0.89^{\mathrm{a}}$ & $2.17 \pm 0.77^{\mathrm{b}}$ & $2.13 \pm 0.56^{\mathrm{b}}$ & 0.001 \\
\hline Moisture (\%) & $71.28 \pm 1.42^{\mathrm{c}}$ & $72.08 \pm 0.59^{\mathrm{b}}$ & $72.69 \pm 1.0^{\mathrm{a}}$ & 0.001 \\
\hline Sarcoplasmic protein solubility $(\mathrm{mg} / \mathrm{g})$ & $39.13 \pm 0.71^{\mathrm{a}}$ & $39.42 \pm 2.28^{\mathrm{a}}$ & $37.96 \pm 1.65^{\mathrm{b}}$ & 0.02 \\
\hline $\mathrm{pH}$ & $5.71 \pm 0.11^{\mathrm{a}}$ & $5.69 \pm 0.17^{\mathrm{a}}$ & $5.58 \pm 0.22^{\mathrm{b}}$ & 0.003 \\
\hline CIE L*2) & $52.09 \pm 1.70^{\mathrm{a}}$ & $49.77 \pm 2.59^{\mathrm{b}}$ & $53.76 \pm 3.66^{\mathrm{a}}$ & 0.001 \\
\hline CIE $a^{* 2)}$ & $4.24 \pm 1.26^{\mathrm{a}}$ & $3.77 \pm 1.68^{\mathrm{a}}$ & $2.65 \pm 1.25^{\mathrm{b}}$ & 0.004 \\
\hline CIE $b^{* 3)}$ & $12.29 \pm 0.88$ & $11.56 \pm 1.40$ & $11.97 \pm 1.48$ & ns \\
\hline Cooking loss (\%) & $17.48 \pm 2.31$ & $17.26 \pm 1.36$ & $17.59 \pm 2.36$ & ns \\
\hline WBSF(N) $)^{4)}$ & $21.72 \pm 1.55$ & $21.54 \pm 1.03$ & $21.29 \pm 1.19$ & ns \\
\hline$d f^{(5)}$ & & & & $2 / 30$ \\
\hline
\end{tabular}

${ }^{\mathrm{a}-\mathrm{c}}$ Mean \pm SE in the same row with different superscript differed significantly $(p<0.05)$

ns, not significant $(p>0.05)$

${ }^{1)}$ CIE L*, lightness

${ }^{2)} \mathrm{CIE} \mathrm{a}^{*}$, redness

${ }^{3)} \mathrm{CIE} \mathrm{b*}$, yellowness

${ }^{4)}$ WBSF, Warner-Bratzler shear force

${ }^{5)} \mathrm{df}$, Numerator/Denominator degree of freedom

Table 2. Breed effect on sensory properties of longissimus lumborum muscle from Duroc, Berkshier and Yorkshire

\begin{tabular}{lcccc}
\hline \hline \multirow{2}{*}{ Items $^{2)}$} & \multicolumn{3}{c}{} & \multirow{2}{*}{ P value } \\
\cline { 2 - 4 } & Duroc & Berkshire & Yorkshire & \\
\hline Tenderness & $56.15 \pm 8.08$ & $60.32 \pm 10.11$ & $53.55 \pm 10.69$ & $\mathrm{~ns}^{1)}$ \\
Juiciness & $64.26 \pm 9.27$ & $58.99 \pm 12.48$ & $62.76 \pm 9.57$ & $\mathrm{~ns}$ \\
Flavor & $63.00 \pm 7.27$ & $62.35 \pm 8.14$ & $61.85 \pm 6.27$ & $\mathrm{~ns}$ \\
Overall acceptability & $64.57 \pm 5.98^{\mathrm{a}}$ & $56.82 \pm 10.66^{\mathrm{b}}$ & $55.35 \pm 5.77^{\mathrm{b}}$ & 0.04 \\
Overall rating & $2.31 \pm 0.35^{\mathrm{a}}$ & $2.02 \pm 0.45^{\mathrm{b}}$ & $1.80 \pm 7.50^{\mathrm{b}}$ & 0.05 \\
df $^{\text {3) }}$ & & & & $2 / 30$ \\
\hline
\end{tabular}

\footnotetext{
${ }^{\mathrm{a}-\mathrm{c}}$ Mean \pm SE in the same row with different superscript differed significantly $(p \leq 0.05)$.

${ }^{1)} \mathrm{ns}$, not significant $(p>0.05)$

${ }^{2)}$ Tenderness, 0 (not tender) to 100 (very tender); juiciness, 0 (not juicy) to 100 (very juicy); flavor, 0 (dislike extremely) to 100 (like extremely); overall acceptability, 0 (dislike extremely) to 100 (like extremely); overall rating was subjective grade, 1 (lowest grade) to 4(highest grade)

${ }^{3)} \mathrm{df}$, Numerator/denominator degree of freedom
} 
ing quality (Table 2) in that Duroc breed received significantly $(p<0.05)$ higher scores on overall acceptability and overall ratings than other two breeds. Brewer et al. (2002) reported that $1 \%$ difference of fatty acid content in pork altered different flavor intensity on panel test, however, in our result, there was not significant difference on flavor score with difference intramuscular fat contents between Duroc and other breeds meats.

The $\mathrm{pH}$ of meat has great influence on objective meat quality and palatability through its effects on water-holding capacity, protein solubility and surface reflectance of meat (Hwang et al., 2003; Joo et al., 1999). Scheffler et al. (2007) reported that abnormal low $\mathrm{pH}$ causes denature of sarcoplasmic and myofibrilar proteins, and it was resulting in pale color and reduced water-holding capacity. In particular, when the rate of postmortem glycolysis was faster and glycolysis activity under slow chilling regime was greater than normal, meats are more susceptible to a higher extent of protein denature (Choi et al., 2010). In the current study, all animals were handled and slaughtered by standard commercial procedures. However, Yorkshire showed significantly $(p<0.05)$ lower $\mathrm{pH}$ than two other breeds. Duroc showed the highest $\mathrm{pH}$ with 5.71 even though that did not a significant differences from Berkshire $(p>0.05)$. The $\mathrm{pH}$ result was reflected on sarcoplasmic protein solubility where Yorkshire LD muscle had significantly $(p<0.05)$ lower solubility than other breeds. This mirrors that Duroc and Berkshire have similar traits in postmortem glycolytic regime, although Duroc meat contained significantly $(p<0.5)$ higher intramuscular fat content than Berkshire.

It has been identified that meat with low $\mathrm{pH}$ uses less oxygen due to decreased activity and/or inactivation of enzymatic oxygen consumption systems (Lindahl et al., 2006). Joo et al. (1999) reported that sarcoplsmic protein solubility negatively correlated with CIE L*, $a^{*}$ and $b^{*}$ for meat color, and our study also showed negative relationship between sarcoplasmic protein solubility and meat color.

According to Hwang et al. (2005)'s report, Berksire had more oxidative fiber type than Yorkshire, it was reflects higher redness on Berkshire meat. The high redness for Duroc and Berkshire is likely confounded by fiber type and ultimate $\mathrm{pH}$ and which are consequently reflected on protein solubility. Low $\mathrm{pH}$ of meat resulted in increased free water at the muscle cell surface, and effected increased reflectance giving the meat a lighter appearance (Rees et al., 2003), but Berkshire showed the lowest lightness $(p<0.05)$ with significantly higher $\mathrm{pH}$ than Yorksire. Current study not measured oxidation of myoglobin, but it is well known that decreased redness was a result of oxidation of myoglobin, clearly reflected in increasing levels of MetMb and a simultaneous decrease in $\mathrm{MbO}_{2}$ levels (Lindahl et al., 2006; Kim et al., 2010). The current data of unexplainable lightness value might be confounded by the different characteristics of myoglobin oxidation between breeds. On the other hand, sarcoplasmic protein solubility showed a significant simple correlation with $\mathrm{CIE} \mathrm{L}^{*}$ values $(\mathrm{r}=-0.45$, data not shown).

WBSF and cooking loss were not differed between the breeds. The results was particularly of interest because the current data showed significant effect of breeds on intramuscular fat content and ultimate $\mathrm{pH}$ which in general have significant effect on water-holding capacity and tenderness (Aaslyng et al., 2003). Crawford et al. (2010) reported that Berkshire was tender than Landrace. The authors noted that higher collagen might force, the more water out from the muscle as a function of shrinkage during cooking, and thus may indicate a breed-specific relationship of meat quality, even though the relationship depends on genetics.

The most important aspect of meat quality is eating quality and usually defined as scores given by panelists for tenderness, juiciness and flavor (Wood et al., 2004). Our data revealed that sensory scores for tenderness, juiciness and flavor were not differed among breeds (Table 2), although Pearson's correlation between intramuscular fat content and overall quality of parameters was relatively high. It has been modeled that muscle $\mathrm{pH}$ affects the distance between myofilaments through its effect on electrostatic repulsion. In addition, the distance between the myofilaments influences in the distribution of water and strength of water bound to muscle proteins (Aaslyng et al., 2003). However, the significant difference in ultimate $\mathrm{pH}$ between breeds was not reflected on sensory juiciness and tenderness, similarly to cooking loss (Table 1). On the other hand, sensory panels identified Duroc was more acceptable overall liking and overall rating than other breeds significantly $(p<0.05)$. In fact, Duroc received numerically higher scores for juiciness and flavor than other breeds, even though there was not significant $(p>$ 0.05 ). Furthermore, Duroc had significantly higher intramuscular fat content and higher $\mathrm{pH}$ than other breeds. The significant factors collectively mirrored on higher overall liking and rating significantly $(p<0.05)$.

The fatty acid composition of LD muscle from three different breed pigs was given in Table 3 . The predomi- 
Table 3. Difference of fatty acid contents of longissimus lumborum muscle from Duroc, Berkshier and Yorkshire

\begin{tabular}{|c|c|c|c|c|}
\hline \multirow{2}{*}{ Fatty acids } & \multicolumn{3}{|c|}{ Breed } & \multirow{2}{*}{$P$ value } \\
\hline & Duroc & Berkshire & Yorkshire & \\
\hline Caprilyc acid (C8:0) & $0.03 \pm 0.02$ & $0.02 \pm 0.01$ & $0.02 \pm 0.01$ & $\mathrm{Ns}^{1)}$ \\
\hline Capric acid (C10:0) & $0.20 \pm 0.06^{\mathrm{ab}}$ & $0.22 \pm 0.06^{\mathrm{a}}$ & $0.17 \pm 0.05^{\mathrm{b}}$ & 0.01 \\
\hline Lauric acid (C12:0) & $0.17 \pm 0.04^{\mathrm{a}}$ & $0.18 \pm 0.04^{\mathrm{a}}$ & $0.14 \pm 0.03^{\mathrm{b}}$ & 0.007 \\
\hline Myristic acid (C14:0) & $2.23 \pm 0.41^{\mathrm{a}}$ & $2.27 \pm 0.50^{\mathrm{a}}$ & $1.81 \pm 0.37^{\mathrm{b}}$ & 0.002 \\
\hline Palmitic acid (C16:0) & $29.49 \pm 4.95^{\mathrm{b}}$ & $34.80 \pm 7.87^{\mathrm{a}}$ & $26.96 \pm 5.88^{\mathrm{b}}$ & 0.001 \\
\hline Palmitoleic acid (C16:1) & $4.50 \pm 1.17$ & $5.13 \pm 2.31$ & $4.33 \pm 1.27$ & ns \\
\hline Stearic acid (C18:0) & $15.30 \pm 3.23^{\mathrm{ab}}$ & $17.34 \pm 3.83^{\mathrm{a}}$ & $14.07 \pm 3.32^{\mathrm{b}}$ & 0.01 \\
\hline Oleic acid (C18:1) & $40.19 \pm 8.43^{\mathrm{a}}$ & $29.85 \pm 11.37^{\mathrm{b}}$ & $38.18 \pm 5.74^{\mathrm{a}}$ & 0.001 \\
\hline Linoleic acid (C18:2) & $6.65 \pm 6.09^{\mathrm{b}}$ & $8.21 \pm 7.02^{\mathrm{b}}$ & $12.87 \pm 5.87^{\mathrm{a}}$ & 0.008 \\
\hline Linolenic acid (C18:3) & $0.57 \pm 0.22^{\mathrm{b}}$ & $0.76 \pm 0.32^{\mathrm{a}}$ & $0.59 \pm 0.18^{\mathrm{b}}$ & 0.04 \\
\hline Aracidic acid (C20:0) & $0.21 \pm 0.05$ & $0.21 \pm 0.05$ & $0.19 \pm 0.04$ & ns \\
\hline Behenic acid (C22:0) & $0.16 \pm 0.11^{\mathrm{b}}$ & $0.28 \pm 0.16^{\mathrm{a}}$ & $0.18 \pm 0.06^{\mathrm{b}}$ & 0.002 \\
\hline Eruric acid (C22:1) & $0.04 \pm 0.02^{\mathrm{b}}$ & $0.06 \pm 0.03^{\mathrm{a}}$ & $0.05 \pm 0.0^{\mathrm{ab}}$ & 0.03 \\
\hline Lignoceric acid (C24:0) & $0.39 \pm 0.34^{b}$ & $0.68 \pm 0.33^{\mathrm{a}}$ & $0.47 \pm 0.16^{\mathrm{b}}$ & 0.003 \\
\hline $\mathrm{SFA}^{2)}$ & $48.19 \pm 7.85^{\mathrm{b}}$ & $56.05 \pm 12.21^{\mathrm{a}}$ & $44.01 \pm 9.38^{\mathrm{b}}$ & 0.001 \\
\hline MUFA $^{3)}$ & $44.58 \pm 7.44^{\mathrm{a}}$ & $35.04 \pm 10.45^{\mathrm{b}}$ & $42.56 \pm 4.46^{\mathrm{a}}$ & 0.001 \\
\hline PUFA $^{4)}$ & $7.22 \pm 6.01^{\mathrm{b}}$ & $8.97 \pm 6.68^{b}$ & $13.46 \pm 13.46^{\mathrm{a}}$ & 0.01 \\
\hline PUFA/SFA & $0.15 \pm 0.15^{\mathrm{b}}$ & $0.16 \pm 0.15^{\mathrm{b}}$ & $0.31 \pm 0.31^{\mathrm{a}}$ & 0.001 \\
\hline$d f^{5)}$ & & & & $2 / 30$ \\
\hline
\end{tabular}

${ }^{\mathrm{a}-\mathrm{c}}$ Mean $\pm \mathrm{SE}$ in the same row with different superscript differed significantly $(p<0.05)$.

${ }^{1)}$ ns, not significant $(p>0.05)$

${ }^{2)}$ SFA, saturated fatty acid

${ }^{3)}$ MUFA, mono unsaturated fatty acid

${ }^{4)}$ PUFA, poly unsaturated fatty acid

${ }^{5)} \mathrm{df}$, Numerator/denominator degree of freedom

nant saturated fatty acids such as palmitic acid was significantly $(p<0.05)$ higher $(34.85 \%)$ in Berkshire while stearic acid was significantly lower (14.1\%) in Yorkshire than other breeds. In addition, capric and myristic fatty acids were significantly $(p<0.05)$ lower in Yorkshire. Oleic acid content was greatly $(p<0.05)$ lower in Berkshire $(29.85 \%)$ than in Duroc $(40.19 \%)$ and Yorkshire (38.18 $\%)$. Even though, we did not tabulate the results because of the limited animal numbers, it was interest to examine correlations between crude fat content and fatty acid concentrations during preliminary data analysis. The results revealed that intramuscular content had significantly positive relation with oleic acid content and significant negative relation with linoleic acid, eruric, behenic and lignoceric contents. The results were in agreement of previous report (Zhang et al., 2007) and indicates that increased intramuscular fat content could increase oleic acid and decrease unsaturated fatty acid content.

On the other hand, the higher level of polyunsaturated fatty acids was observed from Yorkshire (13.46\%) than Berkshire (8.97\%) and Duroc (7.22\%) breeds. The increased linoleic acid was the main driver for Yorkshire (12.87\%), Berkshire (8.21\%) and Duroc (6.65\%) and this lead to the most desirable PUFA/SFA ratio for Yorkshire (0.31) than Berkshire (0.16) and Duroc (0.15). In 1994, The Department of Health of UK recommended that ratio of PUFA/SFA of higher than 0.4 (Alonso, 2010). Enser $e t$ al. (2000) presented that meats naturally had PUFA/SFA ratio of around 0.1 can be a main food source, which is the imbalanced fatty acid intake of today's consumers. PUFA/SFA ration of Yorkshire appeared higher than others, and this result showed importance that Yorkshire will be considered great quality of fatty acid source on breeding. The importance of PUFA ratio in fatty acid, was high digestion rate and improving digestibility of saturated fatty acid with emulsifying agents (Park et al., 2009; Warnants et al., 1998). On the other hand, in terms of eating quality aspect, the higher level of polyunsaturated fatty acids will cause undesirable meat flavor (Cameron et al., 2000).

\section{Relationship of volatile flavor compounds and fatty acids}

Ba et al. (2010) demonstrated that fatty acid composition affected to amount of volatile component from beef, also PUFA generated unpleasant odor, whereas SFA, such 
Table 4. Pearson's correlation coefficients between volatile components and total intramuscular fat (IMF) content and unsaturated fatty acids of longissimus lumborum muscle from Duroc

\begin{tabular}{|c|c|c|c|c|c|c|}
\hline \multirow{2}{*}{ Volatile components } & \multirow{2}{*}{ IMF } & \multicolumn{5}{|c|}{ Unsaturated fatty acids } \\
\hline & & C16:1 & C18:1 & C18:2 & C18:3 & $\mathrm{C} 22: 1$ \\
\hline \multicolumn{7}{|l|}{ Aldehydes } \\
\hline Hexanal & -0.48 & -0.40 & $-0.62 *$ & 0.13 & -0.35 & 0.35 \\
\hline Heptanal & $-0.68 *$ & -0.49 & . & 0.42 & -0.07 & 0.43 \\
\hline Octanal & 0.54 & $\cdot$ & -0.32 & $0.68^{*}$ & -0.01 & 0.36 \\
\hline 2-Octenal & -0.54 & -0.41 & -0.32 & $0.67^{*}$ & 0.18 & 0.60 \\
\hline Decanal & -0.02 & 0.29 & 0.24 & -0.33 & $0.64 *$ & -0.59 \\
\hline E-2-Decenal & -0.54 & -0.33 & -0.31 & 0.49 & -0.04 & 0.61 \\
\hline E,E,2,4-Decadienal & -0.88 & -0.68 & -0.71 & $0.93 *$ & 0.7 & 0.82 \\
\hline Tetradecanal & -0.88 & $0.81^{*}$ & $-0.85^{*}$ & 0.67 & 0.13 & 0.81 \\
\hline \multicolumn{7}{|l|}{ Ketones } \\
\hline 2-Propanone & -0.84 & 0.05 & $-0.51 *$ & -0.13 & -0.52 & -0.33 \\
\hline 2-Butanone & 0.01 & 0.37 & 0.47 & -0.09 & -0.13 & -0.03 \\
\hline 2-Heptanone & -0.38 & -0.49 & -0.18 & 0.23 & -0.06 & 0.41 \\
\hline \multicolumn{7}{|l|}{ Alcohols } \\
\hline 1-Pentanol & -0.65 & -0.34 & -0.49 & 0.57 & 0.01 & 0.05 \\
\hline 2-Furanmethanol & $-0.52 *$ & -0.40 & -0.08 & 0.50 & 0.27 & 0.34 \\
\hline 1-Hexanol & -0.48 & -0.40 & $-0.62 *$ & 0.13 & -0.35 & 0.35 \\
\hline 1-Octen-3-ol & -0.37 & -0.53 & $-0.79 *$ & 0.29 & -0.06 & 0.51 \\
\hline 1-Octanol & $0.57^{*}$ & -0.5 & -0.47 & $0.70^{*}$ & 0.15 & $0.70^{*}$ \\
\hline \multicolumn{7}{|l|}{ Hydrocarbons } \\
\hline 2,5,6-Trimethyloctane & $-0.65^{*}$ & -0.42 & -0.28 & 0.63 & 0.27 & -0.04 \\
\hline 3-Ethyl-2-methyl-1,3-hexadiene & 0.21 & -0.28 & -0.03 & 0.46 & 0.57 & 0.08 \\
\hline 3-Methylnonane & -0.53 & -0.56 & $-0.74 *$ & $0.72 *$ & 0.31 & 0.68 \\
\hline
\end{tabular}

* Significance of the difference between two correlation variables $(p<0.05)$

as linolenic and linoleic acids, developed order acceptability on sensory test (Campo et al., 2003; Wood et al., 2004). As described above, fatty acid composition was different by breed, and/also it had relationship with generation and composition of volatile (Table 3, Table 4). Duroc meat was selected as that contains high levels of intramuscular fat content (3.28\%), and monounsaturated fatty acids (44.58\%) with $40 \%$ of oleic acid and polyunsaturated fatty acid (7.22\%). In the current study, 40 volatile compounds were identified in LD muscle of three breeds using the SPME-GC/MS system. The most abundant flavor substances was total of 20 kind of volatile components, followed by 8 hydrocarbons, 3 ketones, 5 alcohols and 4 hydrocarbons compounds (Table 4).

A large number of volatile components were originated from the oxidation of fatty acids during heating and the comparison was made only with the fat-driven components such as aldehydes, ketones, alcohols and hydrocarbons. On the other hand, amino acid-originated component such as sulphur compounds and heterocycles was exempted; the methyl-branched aldehyde (methylbutanal) are produced from degradation of branched amino acids and sul- fide compounds (dimethyl trisulfide and dimethyl sulfide) are principally formed from the sulfur containing amino acids such as methionine, cysteine and cystine via the Strecker degradation to thiols (Huan et al., 2005). Collectively, it was not the case that the most abundant aldehydes had a negative correlation with oleic acid, while there was positively correlated with linoleic acid. It was been well documented that aldehyde class such as hexanal, heptanal, octanal, E-2-octenal, E-2-decenal, E,E-2,4decadienal and tetradecanal produces pungent, rancid and fatty odors (Brewer, 2009). The results indicate that meat with a higher level of oleic acid generate less level of aldehydes and consequently less rancid and fatty odors. Furthermore, above mentioned aldedehyde species were more likely originated from polyunsaturated linoleic acid. On the other hand, not all the aldehydes were identified in the current study. Tetradecanal was negatively correlated with oleic acid, however there was positive correlation with palmitoleic acid. Furthermore, Decanal, fatty and meaty odors, was positively correlated with linolenic acid. The earlier study (Peterson, 1977) reported that high level of aldehydes contribute undesirable flavor charac- 
teristics to the beef rather than desirable beefy flavor notes and more free radicals of oxidized long chain polyunsaturated fatty acids initiate the oxidation process. These indicate that individual fat-driven flavor components are greatly influenced by composition and polyunsaturated fatty acids are not showed negative effects on meat flavor always if cooked meats are consumed soon.

The earlier studies (Elmore et al., 1999; Wood et al., 2004) indentified that some of the aldehydes are more likely to driven from oleic acid and linoleic acid than from linolenic acid. The total fatty acids, ketone 2-propanone (livery off flavor note), alcohols 1-hexanol and 1octen-3-ol (fruit and roasted meat order) and hydrocarbon 3-methylnonane were negatively correlated with oleic acid. The data indicated that oleic acid content have a great effect on pork flavor. Furthermore, the negative relationship indicates that the meat with high oleic acid generates less fat-driven odor and less alteration to make amino acid driven odor, which in general have more pleasant meat flavor.

\section{Acknowledgements}

It should be acknowledged that this work was, in part, supported by a grant from the Next-Generation BioGreen 21 Program (No. PJ0081162011), Rural Development Administration, Republic of Korea.

\section{References}

1. Aaslyng, M. D., Bejerholm, C., Ertbjerg, P., Bertram, H. C., and Andersen, H. J. (2003) Cooking loss and juiciness of pork in relation to raw meat quality and cooking procedure. Food Qual. Pref. 14, 277-288.

2. Alonso, V., Campo, M. M. Provincial, L., Roncales, P., and Beltrán, J. A. (2010) Effect of protein level in commercial diets on pork meat quality. Meat Sci. 85, 7-14.

3. AOAC (2006) Official method of analysis, 18th ed, Association of Official Analytical Chemists, Washington, DC, Method 991.36.

4. Ba, H. V., Oliveros, M. C., Ryu, K. S. and Hwang, I. H. (2010) Development of analysis condition and detection of volatile compounds from cooked beef by SPME-GC/MS analysis. Korean J. Food Sci. Ani. Resour. 30, 73-86.

5. Bejerholm, C., Aaslyng, M. D. (2003) The influence of cooking technique and core temperature on results of a sensory analysis of pork - depending on the raw meat quality. Food Qual. Pref. 15, 19-30.

6. Brewer, M. S., Jensen, J., Sosnicki, A. A., Fields, B., Wilson, E., and McKeith, F. K. (2002) The effect of pig genetics on palatability, color and physical characteristics of fresh pork loin chops. Meat Sci. 61 249-256.
7. Brewer, M. S. (2009) Irradiation effects on meat flavor. Meat Sci. 81, 1-14.

8. Bryhni, E. A., Kjos, N. P., Ofstad, R., and Hunt, M. (2002). Polyunsaturated fat and fish oil in diets for growing-finishing pigs: effects on fatty acid composition and meat, fat and sausage quality. Meat Sci. 62, 1-8.

9. Cameron, N. D., Warris, P. D., Porter, S. J., and Enser, M. B. (1990) Comparison of Duroc and British landrace pigs for meat and eating quality. Danish Meat Research Institute, Roskilde, Denmark, Manuscript No. 720E.

10. Cameron, N. D., Enser, M., Nute, G. R., Whittington, F. M., Penman, J. C., and Fisken, A. C. (2000) Genotype with nutrition interaction on fatty acid composition of intramuscular fat and the relationship with flavour of pig meat. Meat Sci. 55, 187-195.

11. Campo, M. M., Nute, G. R., Wood, J. D., Elmore, S. J., Mottram, D. S., and Enser, M. (2003) Modelling the effect of fatty acids in odor development of cooked meat in vitro; Part 1-sensory perception. Meat Sci. 63, 367-375.

12. Cho, W. B., Oliveros, M. C., Park, K. M., Do, K. T., Lee, K. H., Seo, K. S., Choi, J. G., Lee, M. J. Choi, B. C., Ryu. K. S., and Hwang, I. H. (2009) Objective and subjective quality characteristics of pork longissimus muscle as a function of the ultimate pH. Korean J. Food Sci. Ani. Resour. 29, 685694.

13. Choi, Y. M., Lee, S. H., Choe, J. H., Rhee, M. S., Lee, S. K., Joo, S. T., and Kim, B. C. (2010) Protein solubility is related to myosin isoforms, muscle fiber types, meat quality traits, and postmortem protein changes in porcine longissimus dorsi muscle. Livestock Sci. 127, 183-191.

14. Crawford, S. M., Moeller S. J., Zerby, H. N., Irvin, K. M., Kuber, P. S., Velleman, S. G., and Leeds, T. D. (2010) Effects of cooked temperature on pork tenderness and relationships among muscle physiology and pork quality traits in loins from Landrace and Berkshire swine. Meat Sci. 84, 607-6121.

15. Edwards, D. B., Bates, R. O., and Osburn, W. N. (2003) Evaluation of Duroc vs Pietrainsired pigs for carcass and meat quality measures. J. Anim. Sci. 81, 1895-1899.

16. Eikelenboom, G., Hoving-Bolink, A. H., and Vander Wal, P. G. (1996) The eating quality of pork; The influence of intramuscular fat. Fleischwirtschaft 3, 18.

17. Ellis, M., Webb, A. J., Avery, P. J., and Brown, I. (1996) The influence of terminal sire genotype, sex, slaughter weight, feeding regim and slaughter-house on growth performance and carcass and meat quality in pigs and on the organoleptic properties of fresh pork. Anim. Sci. 62, 521-530.

18. .Elmore, J. S., Mottram, D. S., Enser, M., and Wood, J. D. (1999) Effect of polyunsaturated fatty acid composition of beef muscle on the profile of aroma volatiles. J. Agric. Food Chem. 47, 1619-1625.

19. Elmore, J. S., Warren, H. E., Mottram, D. S., Scollan, N. D., Enser, M., Richardson, R. I., and Wood, J. D. (2004) A comparison of the aroma volatiles and fatty acid compositions of grilled beef muscle from Aberdeen Angus and Holstein-Friesian steers fed diets based on silage or concentrates. Meat Sci. 68, 27-33. 
20. Enser, M., Richardson, R. I., Wood, J. D., Gill, B. P., and Sheard, P. R. (2000) Feeding linseed to increase the n-3 PUFA of pork; fatty acid composition of muscle, adipose tissue, liver and sausages. Meat Sci. 55, 201-212.

21. Graziotti, G. H., Menéndez, J. M. R., Ríos, C. M., Cossu1, C. M., Bosco, A., Affricano, N O., Ceschel, A. P., Moisá1, S., and Basso, L. (2011) Relationship between myosin isoforms and meat quality traits in pig Semitendinosus neuromuscular compartments. Asian-Aust. J. Anim. Sci. 24, 125-129.

22. Holmer, S. F., McKeith, R. O., Boler, D. D., Dilger, A. C., Eggert, J. M., Petry, D. B., McKeith, F. K., Jones, K. L,. and Killefer, J. (2009) The effects of $\mathrm{pH}$ on shelf-life of pork during aging and simulated retail display. Meat Sci. 82, 86-93.

23. Huff-Lonergan, E., Baas, T. J., Malek, M., Dekkers, J. C. M., Prusa, K., and Rothschild, M. F. (2002) Correlations among selected pork quality traits. J. Anim. Sci. 80, 617-627.

24. Huff-Lonergan, E., and Huff-Lonergan, S. M., (2005) Mechanisms of water- holding capacity of meat: The role of postmortem biochemical and structural changes. Meat Sci. 71, 194-204.

25. Hwang, I. H., Devine, C. E., and Hopkins, D. L. (2003) Review; The biochemical and physical aspects of electrical stimulation on beef and sheep meat tenderness. Meat Sci. 65, 677-691.

26. Hwang, I. H., Park, B. Y., Kim, J. H., Cho, S. H and Lee, J. M. (2005) Assessment of postmortem proteolysis by gelbased proteome analysis and its relationship to meat quality traits in pig Longissimus. Meat Sci. 69, 79-91.

27. Hwang, I. H., Polkinghorne, R., Lee, J. M., and Thompson, J. M. (2008) Demographic and design effects on beef sensory scores given by Korean and Australian consumers. Aust. J. Exptl. Agri. 48, 1387-1395.

28. Huan, Y., Zhou, G., Zhao, G., Xinglian, X. X., and Peng, Z. (2005) Changes in flavor com- pounds of dry-cured Chinese Jinhua ham during processing. Meat Sci. 71, 291-299.

29. Jeremiah, L. E. and Miller, R., (1998) Marbling and pork tenderness; National Pork Board, American Meat Science Association, Champaign, IL, USA.

30. Joo, S. T., Kauffmann, R. G., Kim, B. C., and Park, G. B. (1999) The relationship of sarcoplasmic and myofibrillar protein solubility to color and water-holding capacity in porcine longissimus muscle. Meat Sci. 52, 291-297.

31. Kim, G. D., Jeong, J. Y., Hur, S. J., Han, S. Y., Jeon, J. T., and Joo, S. T. (2010) The relationship between meat color (CIE $\mathrm{L}^{*}$ and $\left.\mathrm{a}^{*}\right)$, myoglobin content, and their influence on muscle fiber characteristics and pork quality. Korean J. Food Sci. Ani. Resour. 30, 626-633.

32. Laack, R. L., Stevens, S. G., and Stalder, K. J. (2001) The influence of ultimate $\mathrm{pH}$ and intramuscular fat content on pork tenderness and tenderization. J. Anim. Sci. 79, 392-397

33. Leong, J., Purchas, R. W., Morel, P. C. H., and Wilkinson, B. H. P. (2010) The effects of excluding animal products from the diet on sensory properties of pork from pigs grown in New Zealand as assessed by Singaporean panellists. AsianAust. J. Anim. Sci. 23, 122 - 130.

34. Lindahl, G., Karlsson, A. H., Lundstrom, K., and Andersen,
H. J. (2006) Significance of storage time on degree of blooming and color stability of pork loin from different crossbreeds. Meat Sci. 72, 603-612.

35. Machiels, D., Van Ruth, S. M., Posthumus, M. A., and Istasse, L. (2003) Gas chromatography-olfactometry analysis of the volatile compounds of two commercial Irish beef meats. Talanta. 60, 755-764.

36. Moon, S. Y., and Li-Chan, E.Y.C (2004) Development of solid-phase microextraction methodology for analysis of headspace volatile compounds in simulated beef flavour. Food Chem. 88, 141-149.

37. Mottram, D. S. (1994) Some aspects of the chemistry of meat flavor. In: The flavor of meat and meat products. Shahidi, F. (ed) Blackie, Glasgow, UK, pp. 210-230.

38. Newcom, D. W., Stalder, K. J., Baas, T. J., Goodwin, R. N., Parrish, F. C., and Wiegand, B. R. (2004) Breed differences and genetic parameters of myoglobin concentration in porcine, longissimus muscle. J. Anim. Sci. 82, 2264-2268.

39. NLCF (2004) Korean Carcass Grading Standard. National Livestock Cooperatives Federation, Seoul, Korea.

40. Obi, T., Matsumoto, M., Miyazaki1, K., Kitsutaka1, K., Tamaki1, M., Takase, K., Miyamoto, A., Oka, T., Kawamoto, Y., and Nakada, T. (2010) Skeletal ryanodine receptor 1-Heterozygous PSE (pale, soft and exudative) meat contains a higher concentration of myoglobin than genetically normal PSE meat in pigs. Asian-Aust. J. Anim. Sci. 23, 12441249.

41. Park, B. Y., Kim, N. K., Lee, C. S., and Hwang, I. H. (2007) Effect of fiber type on postmortem proteolysis in longissimus muscle of Landrace and Korean native black pigs. Meat Sci. 77, 482-491.

42. Park, S. W., Seo1, S. H., Chang, M. B., Shin, I. S., and Paik, I. K. (2009) Evaluation of soybean oil as a lipid source for pig diets. Asian-Aust. J. Anim. Sci. 22, 1311 - 1319

43. Peterson, G. L. (1977) A simplification of the protein assays method of Lowry et al., which is more generally applicable. Ann. Biochem. 58, 743-764.

44. SAS (2007) SAS/STAT Software for PC, Release 9.0, SAS Institute Inc., Cary, NC, USA.

45. Savell, J. W., Mueller. S. L., and Baird, B. E. (2005) The chilling of carcasses. Meat Sci. 70, 449-459.

46. Scheffler, T. L. and Gerrard, D. E. (2007) Mechanisms controlling pork quality development: The biochemistry controlling postmortem energy metabolism. Meat Sci. 77, 7-16.

47. Rees, M. P., Trout, G. R., and Warner, R. D. (2003) The influence of the rate of $\mathrm{pH}$ decline on the rate of ageing for pork: interaction with method of suspension. Meat Sci. 65, 791804.

48. Rule, D. C (1997) Direct transesterification of total fatty acids of adipose tissue of freeze dried muscle and liver with boron-trifluoride in methanol. Meat Sci. 46, 23-32.

49. Yang, H. S., Lee, J. I., Joo, S. T., and Park, G. B. (2009) Effects of dietary glycine betaine on growth and pork quality of finishing pigs. Asian-Aust. J. Anim. Sci. 22, 706 - 711.

50. Warnants, M. J., Oeckel, V., and Boucqui, C. V. (1998) Effects of incorporation of dietary polyunsaturated fatty acids in 
pork back fat on the quality of salami. Meat Sci. 49, 43-54.

51. Wood, J. D., Brown, S. N., Nute, G. R., Whittington, F. M., Perry, A. M., Johnson, S. P., and Enser, M. (1996) Effects of breed, feed level and conditioning time on the tenderness of pork. Meat Sci. 44, 105-112.

52. Wood, J. D., Richardson, R. I., Nute, G. R., Fisher, A. V., Campo, M. M., Kasapidou, E., Sheard, P. R., and Enser, M. (2004) Effects of fatty acids on meat quality: a review. Meat
Sci. 66, 21-32.

53. Zhang, S., Knight, T. J., Stalder, K. J., Goodwin, R. N., Lonergan, S. M., and Beitz, D. C. (2007) Effects of breed, sex, and halothane genotype on fatty acid composition of pork longissimus muscle. J. Anim. Sci. 85, 583-591.

(Received 2011.10.13/Revised 2011.10.18/Accepted 2011.10.19) 